\title{
Incidence and classification of pediatric diffuse parenchymal lung diseases in Germany
}

\author{
Matthias Griese*1, Melanie Haug1, Frank Brasch ${ }^{2}$, Achim Freihorst ${ }^{3}$, \\ Peter Lohse ${ }^{4}$, Rüdiger von Kries ${ }^{5}$, Theodor Zimmermann ${ }^{6}$ and \\ Dominik Hartl ${ }^{1}$
}

\begin{abstract}
Address: ${ }^{1}$ Dr von Haunersches Kinderspital, University of Munich, Lindwurmstr 4a, D-80337 Munich, Germany, ${ }^{2}$ Institut für Pathologie, Klinikum Bremen-Mitte gGmbH, St-Jürgen-Str 1, 28177 Bremen, Germany, ${ }^{3}$ Kinderklinik, Ostalb Klinikum, Im Kälblesrain 1, 73430 Aalen, Germany, ${ }^{4}$ Clinical Chemistry, University of Munich, Marchioninistr 15, 81377 München, Germany, ${ }^{5}$ Institut für Soziale Pädiatrie und Jugendmedizin im Kinderzentrum München, Abteilung für Epidemiologie des Kindes- und Jugendalters, Heiglhofstr 63, 81377 München, Germany and ${ }^{6}$ Universitätskinderklinik Erlangen, Loschgestr 15, 91054 Erlangen, Germany

Email: Matthias Griese* - matthias.griese@med.uni-muenchen.de; Melanie Haug - melanie-haug@T-Online.de; Frank Brasch - Frank.Brasch@klinikum-bremen-mitte.de; Achim Freihorst - achim.freihorst@ostalb-klinikum.de; Peter Lohse - Peter.Lohse@med.uni-muenchen.de; Rüdiger von Kries - ag.epi@lrz.uni-muenchen.de; Theodor Zimmermann - Theodor.Zimmermann@kinder.imed.uni-erlangen.de; Dominik Hartl - Dominik.Hartl@med.uni-muenchen.de

* Corresponding author
\end{abstract}

Orphanet Journal of Rare Diseases 2009, 4:26 doi:10.1 186/1750-II72-4-26

This article is available from: http://www.ojrd.com/content/4/I/26

(c) 2009 Griese et al; licensee BioMed Central Ltd.

This is an Open Access article distributed under the terms of the Creative Commons Attribution License (http://creativecommons.org/licenses/by/2.0), which permits unrestricted use, distribution, and reproduction in any medium, provided the original work is properly cited.

\begin{abstract}
Background: Diffuse parenchymal lung diseases (DPLD) in children represent a rare and heterogeneous group of chronic pulmonary disorders. Despite substantial advances in genetics and pathomechanisms, these often lethal diseases are still under-diagnosed. This is due to the fact that (i) the incidence is low, and (ii) clinical presentation, (iii) disease classification and (iv) specific treatment options are largely unknown.
\end{abstract}

Methods: Here we systematically assessed the incidence, the presentation, the diagnostic yield and treatments of pediatric DPLD in Germany, using the Surveillance Unit for Rare Paediatric Disorders (ESPED).

Results: The incidence of DPLD was 1.32 new cases per I million of children per year. The majority of these children were diagnosed within the first year of life. Overall survival was $87 \%$. Using centralized data entry and stratification tools, the patients were categorized into an advanced classification system based on diagnostic algorithms, including clinical presentations, genetics and/ or histology. Combining molecular and clinical information, this survey provides an etiological overview and specific diagnostic recommendations for children with DPLD.

Conclusions: Standardized surveys and systematic classifications are valuable tools for the clinical handling of children with DPLD and aim to improve the disease understanding and the prognosis of these rare detrimental lung diseases. 


\section{Background}

Diffuse parenchymal lung diseases (DPLD) in children, also called pediatric interstitial lung diseases, comprise a large and heterogeneous group of chronic pulmonary disorders $[1,2]$. These diseases are characterized by impaired gas exchange and radiological diffuse infiltrates and have a substantial morbidity and mortality. The major current challenges in DPLD are difficulties with a lack of confidence concerning the (i) clinical diagnosis classification and resulting (ii) therapeutic options. This is mainly due to the paucity of epidemiological data, classification standards and evidence based treatment recommendations in DPLD. The majority of reports represent single cases or small series and not much information is available on the incidence and the natural course of these diseases in pediatric patients. This results in the perpetuation of imprecise diagnoses and non-systematic management with potential significant therapeutic side effects.

Recently, several attempts have been made to overview the epidemiology and clinical outcome of children with DPLD. A national survey in the United Kingdom and Ireland collected 46 cases of children with histological proven idiopathic interstitial pneumonitis over a three years period [3]. The prevalence for children aged 0-16 years was estimated to be 3.6 cases/million; no numbers on the incidence were reported. Similarly, the task force on chronic interstitial lung diseases in immuno-competent children of the European Respiratory Society reported on a broad variety of cases. A total of 185 prevalent cases (107 with biopsy results available) were retrieved across Europe. Since the number of non-reporting centers remained unknown, no numbers on the prevalence of these diseases could be derived [4]. In these recent studies histology was used alone or, at least to a significant extent, for disease classification. However, as a comprehensive classification of the diseases was not available in these studies, these reports are of limited use for clinical diagnosis and treatment of children with DPLD.

Similarly as for the adult idiopathic interstitial pneumonias, when an international group of experts for the clinical, radiographic, and pathologic features agreed upon a consensus classification in 2002 [5] a novel classification was proposed by a working group on pediatric DPLD [6]. This classification system was primarily based on lung biopsy findings derived from 187 cases in children less than 2 years of age with DPLD collected between July 1999 and July 2004 in eleven children's hospitals in North America. This classification system represents a major step forward towards a thorough definition of pediatric cases of DPLD, because it allows a far-reaching categorization of almost all currently known DPLD entities. The resulting nomenclature dichotomizes the DPLD diseases into entities mainly prevalent in infants (A) and entities occurring at all ages (B). Each group contains 4 subgroups, i.e. diffuse developmental disorders (A1), alveolarization abnormalities (A2), specific conditions of undefined etiology (A3) and surfactant dysfunction disorders (A4). With respect to those entities occurring at all ages (B), the subgroups related to systemic diseases (B1), in immune-intact hosts (B2), in immunocompromised hosts (B3) and disorders masquerading as DPLD (B4).

The goal of this present study was to assess the incidence, classification, the clinical management and the outcome of pediatric DPLD in Germany based on the current DPLD classification system, supported by an established tool for epidemiologic studies on rare diseases, the German ESPED research unit [7].

\section{Methods}

The survey was performed with the help of the German Surveillance Unit for Rare Paediatric Disorders (Erhebungseinheit für seltene pädiatrische Erkrankungen in Deutschland (ESPED)). This survey unit sends out monthly postcards or emails to all paediatric hospitals, usually addressing several responsible persons in each hospital, who report whether or not DPLD has been diagnosed. Between January 1, 2005 and December 31, 2006, monthly 462 cards and emails were sent out simultaneously in Germany. The overall return rate was $97 \%$ for both card and email responses. In case of a positive reply, a detailed questionnaire was sent to the reporting institution. The return rate was $70 \%$. In cases of lacking or incompletely filled out questionnaire, information was attempted to obtain by phone. The number of children under 17 years of age under surveillance was 14393400 .

The case definition included all cases of newly diagnosed patients with DPLD. These were defined as (i) neonates (> 36 weeks of gestation) with chronic (longer than 6 weeks) respiratory distress and disease diagnosing findings in bronchoalveolar lavage, lung biopsy, or identification of disease causing mutations in the genes for the ABCA3transporter, surfactant protein B and C (SP-B, SP-C) and (ii) all children less than 17 years of age with chronic (more than 6 weeks) diffuse parenchymal lung disease. In particular, these disease entities included pulmonary interstitial glycogenosis, persistent tachypnoea of infancy (or neuroendocrine cell hyperplasia in infancy), alveolar proteinosis, chronic pneumonitis of infancy, follicular bronchitis or broncholitis, desquamative interstitial pneumonitis (DIP), lymphocytic interstitial pneumonia (not due to recognized immune deficiency), non-specific interstitial pneumonitis (NSIP), idiopathic pulmonary fibrosis of infancy, pulmonary hemosiderosis, sarcoidosis, hypersensitivity pneumonitis and eosinophilic pneumonias. DPLDs, secondary due to immuno deficiencies, rheumatological or oncological diseases, or a chronic graft-versus- 
Table I: Categorization and diagnosis - Entities mainly prevalent in infants (A)

\begin{tabular}{|c|c|c|c|c|c|c|c|c|}
\hline Patient No. & $\begin{array}{l}\text { Interstitial lung } \\
\text { disease }\end{array}$ & $\begin{array}{l}\text { Final pulmonary } \\
\text { diagnosis }\end{array}$ & $\begin{array}{l}\text { Classifi-cation of } \\
\text { pediatric DPLD* }\end{array}$ & $\begin{array}{l}\text { Additional } \\
\text { diagnosis }\end{array}$ & Center type & $\begin{array}{l}\text { Coop- } \\
\text { Diagnosis*** }\end{array}$ & $\begin{array}{l}\text { Lung biopsy, } \\
\text { result }\end{array}$ & $\begin{array}{l}\text { Genetics SFTPB, } \\
\text { SFTPC, ABCA3 }\end{array}$ \\
\hline 1 & $\begin{array}{l}\text { Related to alveolar } \\
\text { surfactant region }\end{array}$ & $\begin{array}{l}\text { SP-B deficiency, } \\
\text { SFTPB mutations }\end{array}$ & A4 & & $\mathrm{R}$ & yes & $\mathrm{CPI}$ & yes \\
\hline 2 & $\begin{array}{l}\text { Related to alveolar } \\
\text { surfactant region }\end{array}$ & $\begin{array}{l}\text { SP-C deficiency, } \\
\text { SFTPC mutation }\end{array}$ & A4 & GERD & $U$ & no & $\begin{array}{l}\text { NSIP, Cholesterol } \\
\text { pneumonitis }\end{array}$ & yes \\
\hline 3 & $\begin{array}{l}\text { Related to alveolar } \\
\text { surfactant region }\end{array}$ & $\begin{array}{l}\text { ABCA3 two } \\
\text { mutations**, SFTPC } \\
\text { mutation }\end{array}$ & A4 & $\begin{array}{l}\text { Neonatal infection } \\
\text { with E. coli, } \\
\text { hyperglycemia, } \\
\text { anemia }\end{array}$ & $U$ & yes & No & yes \\
\hline 4 & $\begin{array}{l}\text { Related to alveolar } \\
\text { surfactant region }\end{array}$ & $\begin{array}{l}\text { ABCA3 two } \\
\text { mutations** }\end{array}$ & A4 & & $\mathrm{R}$ & yes & $\mathrm{CPI}$ & yes \\
\hline 5 & $\begin{array}{l}\text { Related to alveolar } \\
\text { surfactant region }\end{array}$ & $\begin{array}{l}\text { ABCA3 two } \\
\text { mutations** }\end{array}$ & A4 & Failure to thrive & $U$ & yes & DIP & yes \\
\hline 6 & $\begin{array}{l}\text { Related to alveolar } \\
\text { surfactant region }\end{array}$ & $\begin{array}{l}\mathrm{ABCA} 3 \text { one } \\
\text { mutation, low SP-C } \\
\text { in lavage }\end{array}$ & A4 & Partial IgA deficiency & $U$ & yes & $\begin{array}{l}\text { DIP, post infectious } \\
\text { residuals }\end{array}$ & Yes \\
\hline 7 & $\begin{array}{l}\text { Related to alveolar } \\
\text { surfactant region }\end{array}$ & NSIP & A4 & & $\mathrm{U}$ & no & $\begin{array}{l}\text { NSIP, Cholesterol } \\
\text { pneumonitis }\end{array}$ & n.k. \\
\hline 8 & $\begin{array}{l}\text { Related to alveolar } \\
\text { surfactant region }\end{array}$ & $\begin{array}{l}\text { PAP, juvenile, } \\
\text { sporadic }\end{array}$ & A4 & & $U$ & yes & PAP & No \\
\hline 9 & $\begin{array}{l}\text { Unclear RDS in the } \\
\text { mature neonate }\end{array}$ & $\begin{array}{l}\text { SP-C deficiency, } \\
\text { (extremely low } \\
\text { lavage level) }\end{array}$ & A4, possible & $\begin{array}{l}\text { Partial albinism, } \\
\text { bilateral inner ear } \\
\text { deafness, } \\
\text { microcephalus, } \\
\text { hypertrophic } \\
\text { cardiomyopathy, } \\
\text { diaper rash, failure to } \\
\text { thrive, dyskinesia }\end{array}$ & $U$ & yes & no & Yes \\
\hline
\end{tabular}

*Classification of pediatric DPLD according to Deutsch et al 2007; entities mainly prevalent in infants (A; i.e. diffuse developmental disorders (AI), alveolarization abnormalities (A2), specific conditions of undefined etiology (A3) and surfactant dysfunction disorders (A4)). Entities occurring at all ages (B; i.e. related to systemic diseases (BI), in immune-intact hosts (B2), in

immunocompromised hosts (B3) and disorders masquerading as DPLD (B4)). A4, possible; Ax and Bx denote children with the clear clinical diagnosis of pediatric DPLD, in whom however the diagnostic process was stopped prematurely.

**Two mutations means compound heterozygous or homozygous mutations in the ABCA3 gene

****Diagnosis in co-operation with German consultation network for rare lung diseases

Abbreviations: HSP, Hypersensitivity pneumonitis, NEHI, Neuroendocrine cell hyperplasia of infancy; PAP, pulmonary alveolar proteinosis; NSIP, non-specific interstitial pneumonitis; DIP,

desquamative interstitial pneumonitis; R, regional hospital; U, University hospital; n.d., not determined; SFTPB or SFTPC, gene encoding surfactant protein B or C. 
host-reaction of the lungs following stem cell or solid organ transplantation, were excluded in this study.

The pseudonymized questionnaire asked for sex, age, age at diagnosis, other diagnoses, ethnicity, consanguinity, family history, gestational age at birth and respiratory problems in the neonatal period, pulmonary signs and symptoms, loss of weight, results of diagnosing tests (blood, biopsy, bronchoalveolar lavage, lung function, genetic tests) and therapy for the diffuse parenchymal lung disease diagnosed and was approved by the Bavarian data protection agency. In all cases in which a lung biopsy was obtained, tissue was investigated by light microscopy, including PAS, iron and bombesin stain and thereafter by electron microscopy where indicated.

The detailed information collected was discussed and verified by an independent steering group consisting of pediatric pulmonologists (MG, $\mathrm{AF}, \mathrm{TZ})$, a geneticist (PL), and a pediatric pathologist (FB). Those cases that met the inclusion criteria qualified as DPLD. These cases were included into the study.

The results are reported as individual values. For comparison of categorical variables, the Fisher exact test was used. A two sided p-value of $<0.05$ was considered significant.

\section{Results}

\section{Overall characteristics of the patients}

The overall response rate was excellent and was $97 \%$. Of the 56 cases reported, after review by the steering committee, thirty eight cases were verified as DPLD and included in the final study population (Tables 1,2 and 3). The incidence of pediatric DPLD in Germany was calculated as 1.32 (confidence interval 0.92 to 1.81 ) new cases per 1 million of children per year. The female to male ratio was 1.10. The delay in diagnosis, i.e. the time between initial symptoms and the final diagnosis was on average 2 months (range 0 to 12 months). About one third of the cases manifested their disease within the first year of life (Figure 1). After the first year of life, there was a continuous increase of the proportion of children within a certain age group. Important hints for a genetic cause of the DPLD were obtained from the family history on ethnic background, consanguinity and affection of other family members; this was positive in 6 of the 12 infants with initial symptoms during the neonatal period (Tables 4 and $5)$.

\section{Categorization into the current classification system for pediatric DPLD}

Although all our cases were collected prospectively in 2005 and 2006 and inclusion was not restricted to patients with lung biopsy, the nomenclature of pediatric DPLD proposed in 2007 [6] was taken into account and all cases were attempted to categorize appropriately (Tables 1, 2 and 3, Figure 2).

Cases 1 to 21 were categorized into disorders more prevalent in infancy (A) (Tables 1 and 2). Patients 1-8 were clearly grouped into "related to the alveolar surfactant region" (A4) mainly based on lung biopsy or genetic findings. Patients 9 to 15 had DPLD manifesting in the neonatal period and likely involving the alveolar surfactant region; however definite diagnoses by biopsy were not obtained in these neonates. However it is possible that some of these patients might belong to categories A1 to A3. This could have only been clarified by lung biopsies, which were unfortunately not done. Similarly, patients 16 to 18 manifested their DPLD in infancy, but were only clinically defined by symptoms, radiologic, lung function and bronchoalveolar lavage findings typical for interstitial lung diseases. There were 3 cases (Patients 19-21) classified as "specific conditions of undefined etiology" (A3) and on the basis of biopsy in 2, as neuroendocrine hyperplasia of infancy. No cases with the diagnosis "alveolarization abnormalities" (A2) and "diffuse developmental disorders" (A1) were collected.

Cases 22 to 38 were categorized into disorders occurring at all ages (B) (Table 3). For the diagnosis of many of these entities a lung biopsy is not necessary. Indeed a biopsy was done in 5 cases and the other cases were categorized correctly with high confidence. Due to broadly exclusion of cases related to immunodeficiencies and transplantation (B3) and rheumatological or oncological diseases (B1), we had only one case "related to systemic diseases", i.e. biopsy proven sarcoidosis. The majority of subjects fell into the category "immune-intact hosts" (B2), i.e. were children with hypersensitivity pneumonitis and lastly children 36-38 were merely defined by symptoms, radiologic, lung function and bronchoalveolar lavage findings as typical for interstitial lung diseases, but not by lung biopsy.

\section{Diagnosis of monogenetic diseases}

Genetic analysis may diagnose conditions related to the surfactant system (A4), e.g. as SP-B, SP-C, ABCA3 or GMCSF-receptor deficiencies or other conditions including immuno deficiencies with pulmonary manifestation. In six of the 15 cases known to be analysed for such genes aberrations were found, which lead to a definite molecular diagnosis in cases 1 to 5 . Abnormalities were most frequently detected in ABCA3, followed by SP-C (Tables 1 and 2).

\section{Treatment and outcome}

10 of the 12 patients with initial symptoms within the neonatal period were mechanically ventilated; of those who received exogenous surfactant the response was good 
Table 2: Categorization and diagnosis - Entities mainly prevalent in infants (A), continues table

\begin{tabular}{|c|c|c|c|c|c|c|c|c|}
\hline Patient No. & $\begin{array}{l}\text { Interstitial lung } \\
\text { disease }\end{array}$ & $\begin{array}{l}\text { Final pulmonary } \\
\text { diagnosis }\end{array}$ & $\begin{array}{l}\text { Classifi-cation of } \\
\text { pediatric DPLD* }\end{array}$ & $\begin{array}{l}\text { Additional } \\
\text { diagnosis }\end{array}$ & Center type & $\begin{array}{l}\text { Coop- } \\
\text { Diagnosis**** }\end{array}$ & $\begin{array}{l}\text { Lung biopsy, } \\
\text { result }\end{array}$ & $\begin{array}{l}\text { Genetics SFTPB, } \\
\text { SFTPC, ABCA3 }\end{array}$ \\
\hline 10 & $\begin{array}{l}\text { Unclear RDS in the } \\
\text { mature neonate }\end{array}$ & $\begin{array}{l}\text { Blepharo stenosis } \\
\text { bilateral, } \\
\text { pigmentation } \\
\text { abnormalitis of the } \\
\text { retina, cutis laxa, } \\
\text { minor syndromic } \\
\text { abnormalities, } \\
\text { ventricle septal } \\
\text { defect }\end{array}$ & A4, possible & $\begin{array}{l}\text { VSD, hypoglycemia, } \\
\text { choanal stenosis, } \\
\text { blepharo stenosis }\end{array}$ & $\mathrm{R}$ & yes & no & yes \\
\hline II & $\begin{array}{l}\text { Unclear RDS in the } \\
\text { mature neonate }\end{array}$ & n.d. & A4, possible & $\begin{array}{l}\text { PDA, neonatal } \\
\text { infection, small for } \\
\text { date }\end{array}$ & $\mathrm{R}$ & yes & no & Yes \\
\hline 12 & $\begin{array}{l}\text { Unclear RDS in the } \\
\text { mature neonate }\end{array}$ & $\begin{array}{l}\text { Familial, } \\
\text { pneumothorax }\end{array}$ & A4, possible & $\begin{array}{l}\text { Hyperbilirubinemia, } \\
\text { arterial hypotonia }\end{array}$ & $\cup$ & yes & no & yes \\
\hline 13 & $\begin{array}{l}\text { Unclear RDS in the } \\
\text { mature neonate }\end{array}$ & n.d. & A4, possible & & $\mathrm{R}$ & no & no & yes \\
\hline 14 & $\begin{array}{l}\text { Unclear RDS in the } \\
\text { mature neonate }\end{array}$ & $\begin{array}{l}\text { Pulmonary } \\
\text { hypertension, } \\
\text { recurrent } \\
\text { pneumothoraces }\end{array}$ & A4, possible & $\begin{array}{l}\text { Persistant fetal } \\
\text { circulation, acute } \\
\text { renal failure, central } \\
\text { disorder of muscle } \\
\text { tone and } \\
\text { coordination, } \\
\text { suspected neonatal } \\
\text { infection }\end{array}$ & $\cup$ & yes & no & no \\
\hline 15 & $\begin{array}{l}\text { Unclear RDS in the } \\
\text { mature neonate }\end{array}$ & n.d. & A4, possible & & $\mathrm{R}$ & no & no & n.k. \\
\hline 16 & $\begin{array}{l}\text { No further } \\
\text { categorisation }\end{array}$ & n.d. & $A x$ & $\begin{array}{l}\text { Recurrent airway } \\
\text { infections }\end{array}$ & $\mathrm{R}$ & no & no & n.k. \\
\hline 17 & $\begin{array}{l}\text { No further } \\
\text { categorisation }\end{array}$ & n.d. & $A x$ & $\begin{array}{l}\text { Velofacial syndrome } \\
\text { (CATCH 22) }\end{array}$ & $\mathrm{R}$ & no & no & yes \\
\hline 18 & $\begin{array}{l}\text { No further } \\
\text { categorisation }\end{array}$ & n.d. & $A x$ & & $\mathrm{R}$ & no & n.k. & n.k. \\
\hline 19 & $\begin{array}{l}\text { Infant conditions of } \\
\text { undefined etiology }\end{array}$ & $\mathrm{NEHI}$ & $\mathrm{A} 3$ & GERD & $\cup$ & yes & $\mathrm{NEHI}$ & yes \\
\hline 20 & $\begin{array}{l}\text { Infant conditions of } \\
\text { undefined etiology }\end{array}$ & $\begin{array}{l}\text { Chronic tachypnoe } \\
\text { of infancy (CTI) }\end{array}$ & $\mathrm{A} 3$ & $\begin{array}{l}\text { Hemangioma lower } \\
\text { lip }\end{array}$ & $\mathrm{R}$ & yes & no & yes \\
\hline 21 & $\begin{array}{l}\text { Infant conditions of } \\
\text { undefined etiology }\end{array}$ & NEHI & $\mathrm{A} 3$ & Failure to thrive & $U$ & yes & $\mathrm{NEHI}$ & yes \\
\hline
\end{tabular}

*Classification of pediatric DPLD according to Deutsch et al 2007; entities mainly prevalent in infants (A; i.e. diffuse developmental disorders (AI), alveolarization abnormalities (A2), specific conditions of undefined etiology (A3) and surfactant dysfunction disorders (A4)). Entities occurring at all ages (B; i.e. related to systemic diseases (BI), in immune-intact hosts (B2), in immunocompromised hosts (B3) and disorders masquerading as DPLD (B4)). A4, possible; Ax and Bx denote children with the clear clinical diagnosis of pediatric DPLD, in whom however the diagnostic process was stopped prematurely.

**Two mutations means compound heterozygous or homozygous mutations in the $A B C A 3$ gene

***Diagnosis in co-operation with German consultation network for rare lung diseases

Abbreviations: HSP, Hypersensitivity pneumonitis, NEHI, Neuroendocrine cell hyperplasia of infancy; PAP, pulmonary alveolar proteinosis; NSIP, non-specific interstitial pneumonitis; DIP, desquamative interstitial pneumonitis; R, regional hospital; U, University hospital; n.d., not determined; SFTPB or SFTPC, gene encoding surfactant protein B or C. 
Table 3: Categorization and diagnosis - Entities occurring at all ages (B), continues tables I and 2

\begin{tabular}{|c|c|c|c|c|c|c|c|c|}
\hline Patient No. & $\begin{array}{l}\text { Interstitial lung } \\
\text { disease }\end{array}$ & $\begin{array}{l}\text { Final pulmonary } \\
\text { diagnosis }\end{array}$ & $\begin{array}{l}\text { Classifi-cation of } \\
\text { pediatric DPLD* }\end{array}$ & $\begin{array}{l}\text { Additional } \\
\text { diagnosis }\end{array}$ & Center type & $\begin{array}{l}\text { Coop- } \\
\text { Diagnosis*** }\end{array}$ & $\begin{array}{l}\text { Lung biopsy, } \\
\text { result }\end{array}$ & $\begin{array}{l}\text { Genetics SFTPB, } \\
\text { SFTPC, ABCA3 }\end{array}$ \\
\hline 22 & $\begin{array}{l}\text { Related to lung } \\
\text { vessels/heart }\end{array}$ & $\begin{array}{l}\text { Idiopathic } \\
\text { pulmonary } \\
\text { hemosiderosis }\end{array}$ & $\mathrm{BI}$ & Anemia & $U$ & no & $\begin{array}{l}\text { Pulmonary } \\
\text { hemosiderosis }\end{array}$ & no \\
\hline 23 & $\begin{array}{l}\text { Related to lung } \\
\text { vessels/heart }\end{array}$ & $\begin{array}{l}\text { Idiopathic } \\
\text { pulmonary } \\
\text { hemosiderosis }\end{array}$ & $\mathrm{BI}$ & Celiac disease & $U$ & no & no & n.k. \\
\hline 24 & $\begin{array}{l}\text { Related to } \\
\text { systemic disease }\end{array}$ & Sarcoidosis & $\mathrm{BI}$ & $\begin{array}{l}\text { Familial small } \\
\text { stature, anemia }\end{array}$ & $\mathrm{R}$ & no & Sarcoidosis & n.k. \\
\hline 25 & Immune intact host & HSP & B2 & & $U$ & no & HSP & n.k. \\
\hline 26 & Immune intact host & HSP & B2 & & $U$ & yes & HSP & no \\
\hline 27 & Immune intact host & HSP & B2 & Celiac disease & $\mathrm{R}$ & no & HSP & n.k. \\
\hline 28 & Immune intact host & HSP & B2 & & $U$ & no & no & n.k. \\
\hline 29 & Immune intact host & HSP & B2 & & $U$ & no & no & n.k. \\
\hline 30 & Immune intact host & HSP & B2 & $\begin{array}{l}\text { Insufficiency of } \\
\text { tricuspidal valve }\end{array}$ & $\mathrm{R}$ & no & no & n.k. \\
\hline 31 & Immune intact host & HSP & B2 & & $U$ & yes & no & n.k. \\
\hline 32 & Immune intact host & HSP & B2 & & $\mathrm{R}$ & no & no & n.k. \\
\hline 33 & Immune intact host & HSP & B2 & & $\mathrm{R}$ & no & no & n.k. \\
\hline 34 & Immune intact host & HSP & B2 & & $U$ & no & no & n.k. \\
\hline 35 & Immune intact host & HSP & B2 & $\begin{array}{l}\text { Diabetes mellitus } \\
\text { type I, } \\
\text { hyperthyreosis, } \\
\text { adipositas }\end{array}$ & $\mathrm{R}$ & yes & no & n.k. \\
\hline 36 & $\begin{array}{l}\text { No further } \\
\text { categorisation }\end{array}$ & n.d. & $B x$ & $\begin{array}{l}\text { Status following } \\
\text { Clamydia } \\
\text { pneumoniae } \\
\text { pneumonia }\end{array}$ & $\mathrm{R}$ & no & no & n.k. \\
\hline 37 & $\begin{array}{l}\text { No further } \\
\text { categorisation }\end{array}$ & n.d. & $\mathrm{Bx}$ & & $\mathrm{R}$ & no & no & n.k. \\
\hline 38 & $\begin{array}{l}\text { No further } \\
\text { categorisation }\end{array}$ & n.d. & $\mathrm{Bx}$ & $\begin{array}{l}\text { Adenoids, } \\
\text { hypertrophy of } \\
\text { tonsils, episodes of } \\
\text { upper airway } \\
\text { obstruction }\end{array}$ & $\mathrm{R}$ & no & no & n.k. \\
\hline
\end{tabular}

*Classification of pediatric DPLD according to Deutsch et al 2007; entities mainly prevalent in infants (A; i.e. diffuse developmental disorders (AI), alveolarization abnormalities (A2), specific conditions of undefined etiology (A3) and surfactant dysfunction disorders (A4)). Entities occurring at all ages (B; i.e. related to systemic diseases (BI), in immune-intact hosts (B2), in immunocompromised hosts (B3) and disorders masquerading as DPLD (B4)). A4, possible; Ax and Bx denote children with the clear clinical diagnosis of pediatric DPLD, in whom however the diagnostic process was stopped prematurely.

**Two mutations means compound heterozygous or homozygous mutations in the $A B C A 3$ gene

***Diagnosis in co-operation with German consultation network for rare lung diseases

Abbreviations: HSP, Hypersensitivity pneumonitis, NEHI, Neuroendocrine cell hyperplasia of infancy; PAP, pulmonary alveolar proteinosis; NSIP, non-specific interstitial pneumonitis; DIP, desquamative interstitial pneumonitis; R, regional hospital; U, University hospital; n.d., not determined; SFTPB or SFTPC, gene encoding surfactant protein B or C. 
Table 4: History, symptoms, family history - Entities mainly prevalent in infants (A)

\begin{tabular}{|c|c|c|c|c|c|c|c|c|c|}
\hline $\begin{array}{l}\text { Patient } \\
\text { No. }\end{array}$ & $\begin{array}{l}\text { Gestation } \\
\text { al age } \\
\text { (wks) }\end{array}$ & $\begin{array}{l}\text { Age at } \\
\text { diagnosis } \\
(Y)\end{array}$ & $\begin{array}{l}\text { Respiratory } \\
\text { failure }\end{array}$ & $\begin{array}{l}\text { Tachy-I } \\
\text { Dyspnea }\end{array}$ & $\begin{array}{l}\text { Chronic } \\
\text { cough }\end{array}$ & $\begin{array}{l}\text { Failure to } \\
\text { thrive }\end{array}$ & $\begin{array}{l}\text { Ethnic } \\
\text { background }\end{array}$ & Consanguinity & $\begin{array}{l}\text { Same } \\
\text { disease in } \\
\text { other } \\
\text { family } \\
\text { members }\end{array}$ \\
\hline I & $36 *$ & 0 & yes & yes & n.k. & n.k. & Turkey & yes & yes \\
\hline 2 & $40^{*}$ & 6.5 & yes & yes & n.k. & n.k. & Egypt & no & yes \\
\hline 3 & $40 *$ & 0 & yes & yes & no & n.k. & UAE & n.k. & yes \\
\hline 4 & $38 *$ & 0 & yes & yes & no & no & Syria & yes & no \\
\hline 5 & 40 & 2.92 & yes & yes & n.k. & yes & Germany & no & no \\
\hline 6 & 40 & 0.75 & no & yes & no & no & n.k. & n.k. & no \\
\hline 7 & 40 & 11.25 & no & yes & n.k. & no & Japan/Poland & no & no \\
\hline 8 & n.k. & 9.08 & no & yes & n.k. & yes & n.k. & n.k. & n.k. \\
\hline 9 & $37 *$ & 0.25 & yes & yes & no & no & Turkey & yes & yes \\
\hline 10 & $37 *$ & 0 & yes & yes & no & no & Germany & no & no \\
\hline II & $39 *$ & 0 & yes & yes & n.k. & no & Germany & no & no \\
\hline 12 & $38 *$ & 0 & yes & yes & no & no & Germany & n.k. & yes \\
\hline 13 & 40 & n.k. & no & n.k. & n.k. & no & n.k. & no & no \\
\hline 14 & $38 *$ & 0 & yes & yes & no & no & n.k. & n.k. & n.k. \\
\hline 15 & $40 *$ & 0.42 & yes & yes & n.k. & yes & Germany & no & no \\
\hline 16 & 40 & 1.92 & no & yes & yes & no & Germany & no & no \\
\hline 17 & $36 *$ & 0.17 & no & n.k. & n.k. & yes & Germany & no & no \\
\hline 18 & $34 *$ & 0.00 & yes & n.k. & n.k. & yes & n.k. & no & no \\
\hline 19 & 36 & 0.58 & no & yes & no & no & n.k. & no & no \\
\hline 20 & 38 & 0.33 & yes & yes & n.k. & no & Germany & no & no \\
\hline 21 & n.k. & 1.75 & no & yes & n.k. & yes & Germany & n.k. & no \\
\hline
\end{tabular}

* Initial symptoms within the neonatal period n.k., not known;

Table 5: History, symptoms, family history - Entities occurring at all ages (B), continues table 4

\begin{tabular}{|c|c|c|c|c|c|c|c|c|c|}
\hline $\begin{array}{l}\text { Patient } \\
\text { No. }\end{array}$ & $\begin{array}{l}\text { Gestational } \\
\text { age (wks) }\end{array}$ & $\begin{array}{l}\text { Age at } \\
\text { diagnosis } \\
\text { (Y) }\end{array}$ & $\begin{array}{l}\text { Respiratory } \\
\text { failure }\end{array}$ & $\begin{array}{l}\text { Tachy-I } \\
\text { Dyspnea }\end{array}$ & $\begin{array}{l}\text { Chronic } \\
\text { cough }\end{array}$ & $\begin{array}{l}\text { Failure to } \\
\text { thrive }\end{array}$ & $\begin{array}{l}\text { Ethnic } \\
\text { background }\end{array}$ & Consanguinity & $\begin{array}{l}\text { Same } \\
\text { disease in } \\
\text { other } \\
\text { family } \\
\text { members }\end{array}$ \\
\hline 22 & 40 & 11 & n.k. & n.k. & n.k. & yes & Turkey & yes & no \\
\hline 23 & 40 & 16.5 & no & yes & no & no & $\begin{array}{l}\text { Germany/ } \\
\text { USA }\end{array}$ & no & no \\
\hline 24 & 40 & 13.67 & no & yes & no & no & Turkey & no & no \\
\hline 25 & n.k. & 6.17 & no & yes & yes & no & Germany & no & no \\
\hline 26 & 40 & 10.5 & no & yes & yes & no & Germany & no & no \\
\hline 27 & 36 & 13.5 & no & yes & yes & yes & Germany & no & no \\
\hline 28 & n.k. & 5.67 & no & yes & no & no & Germany & no & no \\
\hline 29 & 39 & 6 & no & yes & yes & no & Germany & no & no \\
\hline 30 & 42 & 8.08 & no & yes & yes & no & Germany & no & no \\
\hline 31 & n.k. & 9.42 & no & yes & no & no & Germany & no & no \\
\hline 32 & 39 & 10.58 & no & yes & no & no & Germany & no & no \\
\hline 33 & 40 & 11.42 & no & yes & yes & no & Germany & no & no \\
\hline 34 & 40 & 12.58 & no & yes & yes & yes & Germany & no & n.k. \\
\hline 35 & n.k. & 14.5 & no & yes & yes & no & Germany & n.k. & no \\
\hline 36 & 40 & 13.92 & no & no & no & no & Germany & no & no \\
\hline 37 & 39 & n.k. & no & yes & no & no & Germany & no & no \\
\hline 38 & n.k. & 3.42 & no & yes & no & no & Germany/n.k. & n.k. & yes \\
\hline
\end{tabular}

* Initial symptoms within the neonatal period n.k., not known; 


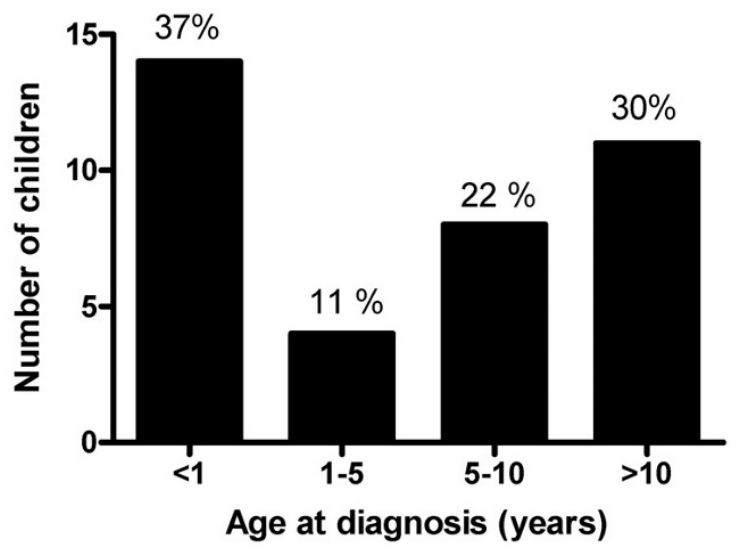

Figure I

Children with diffuse parenchymal lung diseases incident during 2005 and 2006 in Germany divided into different age groups. Given are absolute numbers and the percentages are indicated on top of the columns.

in $60 \%$ of the cases (Table 6 ). In almost all children, systemic steroids were tried initially with a reported response rate of $90 \%$. Of interest, in only two children with hypersensitivity pneumonitis allergen avoidance instead of steroids, i.e. the recommended treatment, were used (Table $7)$. Only in a minority of the patients with pediatric DPLD chloroquine was used (Tables 6 and 7).

Of note, there was additional morbidity from concomitant diagnosis, including gastro-esophageal reflux, failure to thrive, and some auto-immune disorders which were

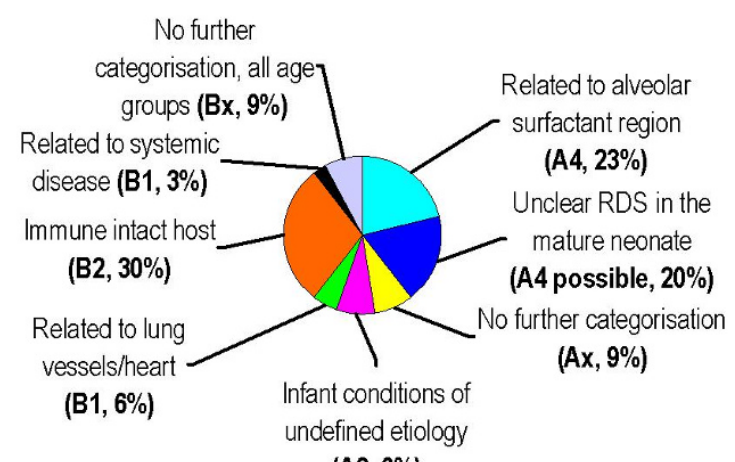

(A3, 9\%)

Figure 2

The pie-chart illustrates the distribution of the $\mathbf{3 8}$ diagnoses classified according to a recent categorization system [6] expressed as percentages. treated separately (Tables 1, 2 and 3). Overall survival was $87 \%$ until the end of the observation period; however among infants with initial symptoms in the neonatal period, immediate survival was only $70 \%$ (Table 6).

\section{Role of the German consultation network for rare lung diseases}

In Germany a working group on rare pediatric lung diseases is established and offers help with the diagnosis and management of cases (http://www.kids-lung-register.eu, http://www.kinderlungenregister.de, $\quad$ http:// www.klreg.eu, http://www.ped-pneumology.de). About $45 \%$ of all cases reported through the German Surveillance Unit for Rare Paediatric Disorders (ESPED) were also managed in cooperation with the German consultation network (Tables 1, 2 and 3). Taken together, definite diagnoses and categorizations were achieved in 25 (cases 1-8 and 19-35) of the 38 cases, whereas in 13 cases this was not satisfactory. Of interest, among the latter cases in none a lung biopsy was done, only 3 were reported from University hospitals and in only 5 the German consultation network was involved.

\section{Discussion}

This study assessed for the first time systematically the incidence and disease classification of pediatric DPLD in Germany, yielding a rate of 1.32 new cases per 1 million of children per year. Diseases caused by monogenetic defects most frequently manifested during infancy and in particular during the neonatal period, whereas those caused by exogenous factors occurred during later childhood and adolescence. The categorisation into a recently proposed classification system for pediatric DPLD was feasible, and demonstrated the need for a more thorough diagnostic effort in a number of cases. Guidance by the German consultation network for pediatric rare lung diseases facilitated a successful diagnosis and may also help in the future to improve treatment strategies.

The primary strength of the study is the use of an established German epidemiological surveillance system ESPED [7], which addressed all children's hospitals on a monthly basis with a very high and representative response rate. Furthermore, this is the first study to generate incidence data on the basis of a recent standardized classification system. The incidence estimate is a minimum since under-ascertainment is likely due to failure to diagnose DPLD or to report diagnosed cases. In order to minimize under-diagnosis all participating pediatric hospitals were given clear instructions regarding case definitions and diagnostic procedures before starting the surveillance. Assessment of potential under-reporting requires at least one additional reporting source. Unfortunately no such second reporting scheme is available for DPLD. In other studies underreporting in ESPED varied 
Table 6: Treatment and outcome - Entities mainly prevalent in infants (A)

\begin{tabular}{|c|c|c|c|c|c|c|}
\hline Patient No. & $\begin{array}{l}\text { Mechanical } \\
\text { ventilation }\end{array}$ & $\begin{array}{l}\text { Surfactant } \\
\text { treatment, } \\
\text { response }\end{array}$ & $\mathrm{O}_{2}$ supply at rest & $\begin{array}{l}\text { Immuno- } \\
\text { suppressive } \\
\text { treatment }\end{array}$ & $\begin{array}{l}\text { Response to } \\
\text { treatment }\end{array}$ & $\begin{array}{l}\text { Long term } \\
\text { out-come }\end{array}$ \\
\hline I & Yes* & yes; good & $\mathrm{I} \mid / \mathrm{min}$ & Systemic steroids & good but transient & died \\
\hline 2 & Yes* & n.k. & n.k. & $\begin{array}{l}\text { Systemic steroids; } \\
\text { Azathioprin; } \\
\text { Hydroxychloroquin }\end{array}$ & $\begin{array}{l}\text { good; } \\
\text { good; } \\
\text { good }\end{array}$ & n.k. \\
\hline 3 & Yes* & yes, good & $100 \%$ & Systemic steroids & none & died \\
\hline 4 & Yes* & yes, good & $30-100 \%$ & $\begin{array}{l}\text { Systemic steroids; } \\
\text { Chloroquin }\end{array}$ & $\begin{array}{l}\text { good; } \\
\text { none }\end{array}$ & died \\
\hline 5 & Yes & n.k. & $2 \mathrm{l} / \mathrm{min}$ & $\begin{array}{l}\text { Systemic steroids; } \\
\text { Hydroxychloroquin }\end{array}$ & $\begin{array}{l}\text { none; } \\
\text { none }\end{array}$ & died \\
\hline 6 & No & n.k. & $21 / \mathrm{min}$ & Systemic steroids & n.k. & alive \\
\hline 7 & No & n.k. & no & Systemic steroids & good & n.k. \\
\hline 8 & n.k. & n.k. & $4 \mathrm{l} / \mathrm{min}$ & Systemic steroids & n.k. & alive \\
\hline 9 & Yes* & yes, none & $80-100 \%$ & Systemic steroids & n.k. & died \\
\hline 10 & Yes* & yes, none & transient & Systemic steroids & good & alive \\
\hline 11 & Yes* & yes, good & $\mathrm{I} \mathrm{l} / \mathrm{min}$ & Systemic steroids & good but transient & alive \\
\hline 12 & Yes* & yes, good & transient & No steroids & & alive \\
\hline 13 & No & n.k. & n.k. & n.k. & & n.k. \\
\hline 14 & Yes* & yes, none & transient & No steroids & & alive \\
\hline 15 & No* & no & $\mathrm{I}-2 \mathrm{I} / \mathrm{min}$ & Systemic steroids & good & n.k. \\
\hline 16 & No & no & n.k. & n.k. & & n.k. \\
\hline 17 & No* & n.k. & & n.k. & & n.k. \\
\hline 18 & Yes* & n.k. & & n.k. & & n.k. \\
\hline 19 & No & no & $0,7-2 \mathrm{l} / \mathrm{min}$ & Systemic steroids & n.k. & alive \\
\hline 20 & Yes & no & $\mathrm{I} \mid / \mathrm{min}$ & No steroids & & alive \\
\hline 21 & No & n.k. & $2 \mathrm{l} / \mathrm{min}$ & Systemic steroids & good & alive \\
\hline
\end{tabular}

* Initial symptoms within the neonatal period; ** Follow up information was obtained one year after inclusion of the subject into the survey n.k., not known;

between 38 - 76\% [7], with higher reporting rates for the more severe and chronic conditions such as metabolic diseases and diabetes. Among the 21 cases of pediatric DPLD occurring in infancy and categorized into "disorders more prevalent in infancy" (A), a satisfying diagnosis was established in 11 . In 10 cases diagnostic efforts were stopped prematurely. Similar unresolved cases are less likely to be reported to the registry, whereas those with a definite diagnosis are more likely to be reported.

The categorization system applied here is based on a study that used lung tissue as the starting data point [6]. Therefore those cases that needed biopsy for diagnosis cannot be definitely categorized. Other differences are related to our case definition which excluded premature infants and children which cleared their disease within six weeks.

Recently the BPOLD registry, a web-based registry for rare (orphan) pediatric lung diseases in the United Kingdom, was established. In addition to interstitial lung diseases six other rare lung conditions were collected [8]. The advantage of the system is a rapid and direct communication between the involved sites. This may allow addressing the general problem that many of the pediatric DPLD are initially diagnosed and treated in regional hospitals, as can be seen by the rate of $50 \%$ of all cases reported in our study from regional hospitals. A disadvantage is that of the 15 cases of interstitial lung disease reported over a one year period only one case was confirmed. It is of importance to offer assistance in the management of these rare diseases. This is feasible by advice on genetic testing which was done in our study in 6 out of the 13 cases not satisfactory diagnosed initially.

The current study clearly showed that pediatric DPLD represent orphan diseases, which need to be more carefully addressed by both, clinicians and policymakers, health regulators and government. This is particularly relevant in the diseases occurring in infants, as the mortality is high (Table 6). Appropriate diagnostic classification and categorization is of great importance for indicating a correct prognosis and treatment in DPLD. The clinicians responsible have to be very insistent as often expensive genetic tests or relatively invasive procedures (open lung biopsy), which they are not familiar with on a routine basis, have to be performed adequately. Similarly, the right therapeutic measures need to be systematically installed and supervised. Such tasks should be done in close cooperation with or in an experienced centre. Web-based communication and consultation systems may facilitate the manage- 
Table 7: Treatment and outcome - Entities occurring at all ages (B), continues table 6

\begin{tabular}{|c|c|c|c|c|c|c|}
\hline Patient No. & $\begin{array}{l}\text { Mechanical } \\
\text { ventilation }\end{array}$ & $\begin{array}{l}\text { Surfactant } \\
\text { treatment, } \\
\text { response }\end{array}$ & $\mathrm{O}_{2}$ supply at rest & $\begin{array}{l}\text { Immuno- } \\
\text { suppressive } \\
\text { treatment }\end{array}$ & $\begin{array}{l}\text { Response to } \\
\text { treatment }\end{array}$ & $\begin{array}{l}\text { Long term } \\
\text { out-come** }\end{array}$ \\
\hline 22 & No & n.k. & & n.k. & & n.k. \\
\hline 23 & No & n.k. & & Systemic steroids & good & alive \\
\hline 24 & No & no & & Systemic steroids & good & n.k. \\
\hline 25 & No & n.k. & & Systemic steroids & good & alive \\
\hline 26 & No & n.k. & no & Systemic steroids & good & alive \\
\hline 27 & No & n.k. & $0.5-1 \mathrm{l} / \mathrm{min}$ & Systemic steroids & good & alive \\
\hline 28 & No & no & & Systemic steroids & good & alive \\
\hline 29 & No & no & $\mathrm{I}-2 \mathrm{l} / \mathrm{min}$ & Systemic steroids & good & alive \\
\hline 30 & No & no & $21 / \min$ & $\begin{array}{l}\text { No steroids, } \\
\text { allergen removal }\end{array}$ & good & alive \\
\hline 31 & No & n.k. & no & $\begin{array}{l}\text { No steroids, } \\
\text { allergen removal }\end{array}$ & good & alive \\
\hline 32 & No & no & & Systemic steroids & good & alive \\
\hline 33 & No & no & & Systemic steroids & good & alive \\
\hline 34 & No & n.k. & & Systemic steroids & good & alive \\
\hline 35 & No & n.k. & & Systemic steroids & good & alive \\
\hline 36 & No & no & & Systemic steroids & good & n.k. \\
\hline 37 & No & n.k. & $0,3 \mathrm{l} / \mathrm{min}$ & n.k. & & n.k. \\
\hline 38 & n.k. & n.k. & no & n.k. & & n.k. \\
\hline
\end{tabular}

* Initial symptoms within the neonatal period; ** Follow up information was obtained one year after inclusion of the subject into the survey n.k., not known;

ment of these patients. Their implementation will allow easy access to reference pediatric pathologists, radiologists and other experts. Lastly, the pseudonymised collection of rare cases, best in association with bio-banked materials, and the international integration of national networks, will allow a more rapid progress for patients with these cumbersome illnesses.

The knowledge of a causal mutation and, if sufficient numbers of similar cases are collected, the possibility of a reliable prediction of response to therapy and the prognosis, are important from an individual perspective, as uncertainty causes significant stress and anxiety for many patients and their families [9]. For instance in patient 1 , bearing lethal SP-B mutations where therapeutic interventions like steroids or whole lung lavages are known to be ineffective [10], unnecessary treatments can be avoided. Among the mutations in genes leading to pediatric DPLD related to the alveolar surfactant region, $\mathrm{ABCA} 3$ mutations were the most frequent ones (Table 1). Based on these data and those obtained previously [11-13], the diagnostic workup of neonates and infants with suspected DPLD, a non-resolving course and exclusion of other causes, should include initial genetic testing for SFTPB and SFTPC as these are rather small genes, followed by analysis of the large $\mathrm{ABCA} 3$ gene. If genetic testing remains negative, lung biopsy is the next consequent step. In older children lung biopsy may be done prior to the genetic tests, since by this strategy several other entities which cannot be diagnosed genetically yet, might be diag- nosed. We found that all ABCA3 mutations identified were different from each other and not described previously; they will be the topic of a separate future report.

\section{Conclusions}

We present the incident cases of pediatric DPLD in Germany over a two year period and demonstrate that particularly those cases which were assessed with the help of the German consultation network for pediatric rare lung diseases, could definitely be diagnosed and categorized into an advanced classification system. We suggest that systematic surveys, disease classification and clinical management systems represent a critical prerequisite for future improvements of treatment and prognosis in the rare children with DPLD.

\section{Abbreviations}

DPLD: Diffuse parenchymal lung diseases; ESPED: Erhebungseinheit für seltene pädiatrische Erkrankungen in Deutschland.

\section{Competing interests}

The authors declare that they have no competing interests.

\section{Authors' contributions}

GM designed the study, participated in and lead the categorization of the subjects, and wrote the manuscript, HM and HD collected, categorized and organized the data, FA, $\mathrm{ZT}, \mathrm{LP}$, and BF discussed and verified the cases, HD and KR organized and supervised the performance of the study 
instrument. All authors participated in drafting the manuscript and approved the final manuscript.

\section{Acknowledgements}

The authors especially acknowledge the constant help of Mrs. Heinrich, secretary of the Erhebungseinheit für seltene pädiatrische Erkrankungen in Deutschland (ESPED) office in Düsseldorf, Germany. The authors would like to thank all the reporting physicians who helped through their cooperation in collecting the data for the present study: Dr. Rieger, Robert-KochKrankenhaus, Apolda; Dr. Generlich, Krankenhaus Lichtenberg, Berlin; Dr. Reitz, Krankenhaus Neukölln, Berlin; Dr. Stücklin, Univ.-Kinderklinik, Bonn; Dr. Dahlem, Klinikum Coburg, Coburg; Dr. Gröbel, Klinikum Lippe-Detmold, Detmold; Dr. Wangemann, St.-Johannes-Hospital, Duisburg; Dr. Schneider, Univ.-Kinderklinik, Frankfurt; Dr. Steiß, Kinderklinik Gießen, Gießen; Dr. Hellwege, Univ.-Kinderklinik, Hamburg; Dr. Laux, Allg. Krankenhaus Barmbek, Hamburg; Dr. Lemke, Krankenhaus Wilhelmstift, Hamburg; Dr. Richter, Kinderkrankenhaus auf der Bult, Hannover; Dr. Schwerk, Medizinische Hochschule, Hannover; Dr. Shamdeen, Univ.-Kliniken, Homburg/Saar; Dr. Härtel, Universitätsklinikum Schleswig-Holstein, Lübeck; Dr. Kamin, Univ.-Kliniken, Mainz; Dr. Kern, Elisabeth-Krankenhaus, Mönchengladbach; Dr. Steiner, Kreiskrankenhaus, Rendsburg; Dr. Schneider, Klinikum am Steinenberg, Reutlingen; Dr. Simunovic, Kreiskrankenhaus, Reutlingen; Dr. Breuel, Universitäts-Kinderklinik, Rostock; Dr. Mihatsch, Diakoniekrankenhaus, Schwäbisch Hall; Dr. Ahring, Allg. Krankenhaus, Viersen; Dr. Renner, Fachkliniken Wangen, Wangen. The paper contains parts of the thesis of Melanie Haug.

\section{References}

I. Fan LL, Deterding RR, Langston C: Pediatric interstitial lung disease revisited. Pediatr Pulmonol 2004, 38:369-378.

2. Clement $A$, Eber $E$ : Interstitial lung diseases in infants and children. Eur Respir J 2008, 31:658-666.

3. Dinwiddie R, Sharief N, Crawford O: Idiopathic interstitial pneumonitis in children: A national survey in the United Kingdom and Ireland. Pediatr Pulmonol 2002, 34:23-29.

4. Clement A, Allen J, Corrin B, Dinwiddie R, le Pointe HD, Eber E, Laurent G, Marshall R, Midulla F, Nicholson AG, Pohunek P, Ratjen F, Spiteri $\mathrm{M}$, de Blic J: Task force on chronic interstitial lung disease in immunocompetent children. Eur Respir J 2004, 24:686-697.

5. American Thoracic Society/European Respiratory Society International Multidisciplinary Consensus Classification of the Idiopathic Interstitial Pneumonias. This Joint Statement of the American Thoracic Society (ATS), and the European Respiratory Society (ERS) was adopted by the ATS Board of Directors, June $200 \mathrm{I}$ and by The ERS Executive Committee, June 2001. Am J Respir Crit Care Med 2002, 165:277-304.

6. Deutsch GH, Young LR, Deterding RR, Fan LL, Dell SD, Bean JA, Brody AS, Nogee LM, Trapnell BC, Langston C, Albright EA, Askin FB, Baker P, Chou PM, Cool CM, Coventry SC, Cutz E, Davis MM, Dishop MK, Galambos C, Patterson K, Travis WD, Wert SE, White FV: Diffuse lung disease in young children - Application of a novel classification scheme. Am J Respir Crit Care Med 2007, 176: II 20-II28.

7. von Kries R, Heinrich B, Hermann M: Pädiatrische Epidemiologie in Deutschland: Forschungsinstrument ESPED (Erhebungseinheit für seltene pädiatrische Erkrankungen in Deutschland). Monatsschr Kinderheilkd 200 I, I49: I 19I-I I97.

8. Laverty A, Jaffe A, Cunningham S: Establishment of a web-based registry for rare (orphan) pediatric lung diseases in the United Kingdom: The BPOLD registry. Pediatr Pulmonol 2008, 43:45I-456.

9. de Vries J, Drent M: Quality of life and health status in interstitial lung diseases. Curr Opin Pulm Med 2006, I 2:354-358.

10. Palomar LM, Nogee LM, Sweet SC, Huddleston CB, Cole FS, Hamvas $A$ : Long-term outcomes after infant lung transplantation for surfactant protein B deficiency related to other causes of respiratory failure. J Pediatr 2006, 149:548-553.

II. Hartl D, Griese M: Interstitial lung disease in children - genetic background and associated phenotypes. Respir Res 2005, 6:.
12. Hallman M, Haataja R: Genetic basis of respiratory distress syndrome. Front Biosci 2007, 12:2670-2682.

13. Wert SE, Whitsett JA, Nogee LM: Genetic disorders of surfactant dysfunction. Pediatr Dev Pathol 2009, 1 2:253-274.
Publish with Biomed Central and every scientist can read your work free of charge

"BioMed Central will be the most significant development for disseminating the results of biomedical research in our lifetime. "

Sir Paul Nurse, Cancer Research UK

Your research papers will be:

- available free of charge to the entire biomedical community

- peer reviewed and published immediately upon acceptance

- cited in PubMed and archived on PubMed Central

- yours - you keep the copyright

Submit your manuscript here:

http://www.biomedcentral.com/info/publishing_adv.asp
BiolMedcentral 